\title{
THE USE AND ABUSE OF JOHN CALVIN IN RICHARD HOOKER'S DEFENCE OF THE ENGLISH CHURCH
}

\author{
DAVID NEELANDS* \\ Trinity College, University of Toronto
}

\begin{abstract}
At times Richard Hooker (1554-1600), as an apologist for the Church of England, has been treated as "on the Calvinist side", at others as an "anti-Calvinist". In fact, Hooker and his Church were dependent on John Calvin in some ways and independent in others. Hooker used recognized sources to paint a picture of Calvin and his reforms in Geneva that would negatively characterize the proposals and behaviour of those he opposed in the Church of England, and yet he adopted Calvinist positions on several topics. A judicious treatment of Hooker's attitude to John Calvin requires careful reading, and an understanding of the polemical use of the portrait of Calvin. Calvin was indeed grave and learned, but he was human and, as an authority, inferior to the Church Fathers, who were formally recognized as authorities in the Church of England.
\end{abstract}

KEY WORDS: Richard Hooker, Calvin, Calvinism, sanctification, internal witness of the Holy Spirit, predestination, Presbyterian system

\section{Introduction}

Although Calvin has, since the eighteenth century, frequently been interpreted as the theological genius behind the Church of England's theological position, especially expressed in the Thirty-Nine Articles of Religion (1563, 1571), such a conclusion is historically inaccurate. Voices of the Continental Reformation were indeed profoundly important in the development of officially-approved English doctrinal and disciplinary standards, but Calvin's voice itself came relatively late in the process, which was well under way by the mid 1530s and before Calvin had published the first edition of the Institutes. In fact, although Calvin's influence grew as the century progressed, Calvinism was not officially accepted until the middle of the Seventeenth

* DAVID NEELANDS is Dean and Professor in the Faculty of Divinity, Trinity College, Toronto. He studied in Toronto and Oxford, and received the degree Doctor of Theology from Trinity College and the University of Toronto.

(C) EMANUEL UNIVERSITY of ORADEA

PERICHORESIS 10.1 (2012) 
Century, when it was received in the distinctive form of developed English (and Scottish) Puritanism, and expressed in the Westminster Confession $(1647,1648)$. At first, the formative influences for Reformation in England were Lutheran, and expressed in the documents of the Lutheran conversations of the 1530s; Lutheran influence was gradually replaced by the greater influence of Bullinger's Zurich, which remained important in England long after Calvin's ascendency in the Reformed world; and by the Rhineland influence of Martin Bucer, and of Peter Martyr Vermigli, which rose to the surface at precisely the moment when the Church of England's institutions were given more-or-less their definitive form. ${ }^{1}$ As government and divines undertook the defence of the settlement in the reign of Queen Elizabeth, Calvin's name was inevitably associated with positions that were not of the Church of England-particularly on the questions of Presbyterian church polity, of forms of public worship, of the authority of the magistrate in ecclesiastical matters, and of such doctrinal discussions as unconditional reprobation, assurance, and the self-authenticating character of scripture supreme over the voice of the church. That said, Calvin's account of renewal or sanctification in the redeemed person, and his account of the presence of Christ in the Eucharist in terms of instrumentalism, were generally absorbed within the Church of England, without much support from the officially approved doctrinal statements. ${ }^{2}$ Thus, when Hooker observes against those who wish to introduce changes in various institutions and practices of the Church of England to conform to Genevan ways, Hooker's "that which expecially concerneth our selves, in the present matter we treate of, is the state of reformed religion..." ${ }^{3}$ must be seen as interpreting a tradition that acknowledges the Reformation and that includes John Calvin, as well as the long process of conversations including other figures that have taken place over generations and that did not necessarily include Calvin's innovations.

1 See, for instance, David Neelands, "Peter Martyr Vermigli and the Thirty-Nine Articles of the Church of England", A Companion to Peter Martyr Vermigli (Leiden: Brill, 2009), 355-374, for the complex arguments that show the probability that Peter Martyr is the most important influence in the composition of Article 17 "On Predestination and Election", and the unlikelihood that Calvin was any positive influence at all.

2 See David Neelands, "Justification and Richard Hooker the Pastor", Lutheran and Anglican. Essays in Honour of Egil Grislis (St. John's College Press, University of Manitoba, 2009), 171-176, and "Christology and the Sacraments", ed. by W. J. Torrance Kirby, $A$ Companion to Richard Hooker (Leiden: Brill, 2008), 369-402.

3 The Folger Library Edition of the Works of Richard Hooker (hereafter FLE), IV.14.7; vol. 1, 344.4-6.

PERICHORESIS 10.1 (2012) 


\section{Attitude to John Calvin}

With respect to John Calvin, Richard Hooker (who was born when Calvin was 45 years old, and who rose to become the voice of the defence of the institutions of the Church of England by the time he died in 1600) has been identified as an "anti-Calvinist". ${ }^{4} \mathrm{He}$ was also identified as "on the Calvinist side" by those who moved away from Calvinism in the seventeenth century. ${ }^{5}$ But neither by itself is an adequate assessment.

Hooker almost certainly studied the Institutes of the Christian Religion thoroughly, possibly under the direction of his tutor, John Reynolds. ${ }^{6}$ And, although he claims to have "collected" his account of Calvin's reforms in Geneva from the "learned guides and pastors" of Geneva, in fact he depends almost entirely on Theodore Beza's biography of Calvin published in $1576 .^{7}$

Hooker refers to John Calvin frequently, but in a consistently ambivalent fashion, at once giving him honour and relativizing him. In the Preface to the Lawes, for instance, Hooker identifies Calvin as the "founder" of the proposed "discipline" of the Puritans, and does so with apparent words of praise: but see Hargrave's treatment of Hooker's "Calvinist debates", which is very thorough. Hargrave ignores the material in the Dublin fragments. O. T. Hargrave, The Doctrine of Predestination in the English Reformation (unpublished PhD thesis, Nashville, Tennessee: Vanderbilt University, 1966), 228-234.

$5 \quad$ See reference to Henry Hammond below.

FLE 6.405, note on 1:3.31-32.

FLE 6.69, fn 144. Beza's Life of John Calvin, published in Latin in 1576, was followed by the scurrilous biography of Calvin published in French in 1577 by Calvin's old adversary, Jerome Bolsec. As a recent biographer of Calvin has noted, "Calvin, according to Bolsec, was irredeemably tedious and malicious, bloodthirsty and frustrated. He treated his own words as if they were the word of God, and allowed himself to be worshipped as God. In addition to frequently falling victim to his homosexual tendencies, he had a habit of indulging himself sexually with any female within walking distance. According to Bolsec, Calvin resigned his benefices at Noyon on account of the public exposure of his homosexual activities. Bolsec's biography makes much more interesting reading than those of Théodore de Béze or Nicolas Colladon; nevertheless, his work rests largely upon unsubstantiated anonymous oral reports deriving from 'trustworthy individuals' (personnes digne de foy), which modern scholarship has found of questionable merit". Alister E. McGrath, A Life of John Calvin (Oxford: Blackwell, 1990), 16-17. Bolsec's account may be a symptom of what Calvin's many critics came to say and believe. Hooker was not one of these. 
A founder [your Discipline] had, whome, for mine owne part, I thinke incomparably the wisest man that ever the french Church did enjoy, since the houre it enjoyed him. ${ }^{8}$

The precision of the allusion should be noted. Calvin is treated as a figure of the French, and not the Genevan Church: that is, he would be a "foreign" and interfering influence in Geneva (and, for that matter, in England), had he not been invited to assist and dramatically invited by the Genevans to return. ${ }^{9}$ The Church of England, for its part, is an integral and separate member of the universal church, as much as the churches of Rome, Corinth and Ephesus, without dependence on the churches of Saxony or Geneva. ${ }^{10}$ Hooker claims that the French church has not seen his like since: that does not mean he was as great as the French giants Hilary, Prosper and others who went before. ${ }^{11}$ Hooker generally shows a reverence for Calvin, whose reputation, he notes, was built both on the strength of the Institutes and on his thorough biblical commentaries, rather than his strengths as a preacher or a reformer of church order. ${ }^{12}$ Hooker undoubtedly follows Calvin in some places where the English formularies ${ }^{13}$ are silent, for instance in the account of the Eucharist in Book V of the Lawes,

9 Calvin was French by birth and education; Geneva was a republic, claimed by Savoy, and not part of France itself; it was not legally part of Switzerland until 1815. At the Synod of Dort twenty-four years after Hooker's Preface was written, Geneva was clearly not identified as part of the French Church, but as an Imperial Free City sending its own delegates. The French government prohibited the attendance of the four delegates elected by the Reformed French Church.

10 Compare Hooker's omission of mention of Geneva as a church: "the Church of Rome, Corinth, Ephesus, England, and so the rest". III.1.14; FLE 1:206.16-17.

11 Egil Grislis gives an extended summary of the variety of interpretations that have been given of this text and of the attitude of Hooker to Calvin. "The Hermeneutical Problem in Richard Hooker", ed. by W. Speed Hill, Studies in Richard Hooker (Cleveland, OH: Case Western Reserve, 1972), 173, 203, note 55.

12 Preface 2.8; FLE 1.10.28-33. Hooker appears to accept the justice of Calvin's international reputation in this passage, but not the uncritical and un-English following of him in matters of church polity by Hooker's English adversaries.

13 Although Article 25 of the Thirty-Nine Articles of Religion includes the phrase "certain sure witnesses and effectual signs of grace", which has been interpreted as expressing "symbolic instrumentalism", a Bucerian or Calvinist account, they are in fact directly taken to the Augsburg Confession and the Thirteen Articles, and are a relic of the early Reformation influence of the Lutherans in England. Gerald Bray, Documents of the English Reformation (Cambridge: J. Clarke, 1994), 198. 
although Calvin is not cited ${ }^{14}$ and in his assumptions about sanctification in Discourse on Justification. ${ }^{15}$ But John Calvin as a church authority carried himself with an inappropriate lack of humility, a characteristic suggested even by his sympathetic observers ${ }^{16}$ even though his work in Geneva was commendable. The solutions he instituted in Geneva would not necessarily be appropriate for the Church of England, which already had episcopacy and a central authority, the king, who could reform the church without refounding it. His uncritical followers err in a dangerous veneration of Calvin, because they forget his human frailty. ${ }^{17}$ In particular, Hooker's critics, the authors of $A$ Christian Letter, who accused him of dangerous novelty, err in promoting Calvin to an authority apparently above Scripture and the patristic authors:

What should the world doe with the old musty DD [doctors?]? Forever Alleage scripture and shew it alleaged in the sense that Calvin alloweth, and it is of more force in any mans defense, and to the proofe of any assertion, than if ten thousand Augustines, Jeromes, Chrysostomes, Cyprians, or whosoever els were brought foorth. Doe we not daily see that men are accused of heresie for holding that which the fathers held, and that they never are cleere till they find not somewhat in Calvin to justify themselves? ${ }^{18}$

V.67. See Francis Paget, An Introduction to the Fifth Book of Hooker's Treatise of the Laws of Ecclesiastical Polity (Oxford: Clarendon, 1899), 180-182.

15 Justification 3: 5:109.6-14; Institutes III.3; III.17.11,12 (i, 814-816). There was some consonance, as Hooker noted, between this Calvinistic treatment of sanctification, and the scholastic theology of Thomas Aquinas. See Neelands, The Theology of Grace of Richard Hooker (Unpublished ThD Thesis, Trinity College and University of Toronto, 1988), 38-46.

16 See for instance, such astonishing statements as the following in a sympathetic and accurate modern commentator on Calvin. "The reformer himself, increasingly convinced that he was acting solely by virtue of a divine mission, did not admit discussion of his ideas". "[Calvin] so completely identified his own ministry with the will of God that he considered Ameaux's words as an insult to the honour of Christ aimed at the person of one of his ministers... A pastor of the country-side dared to criticize Calvin's attitude in this affair: he was immediately unfrocked". François Wendel, Calvin (London: Collins, 1965), 82, 86. In his last days, Calvin himself referred to the patience of the Senate in Geneva for "having borne patiently with my vehemence, which was sometimes carried to excess", and to his peevishness when ill to the Ministers of Geneva. Theodore Beza, "Life of Calvin", Selected Works of John Calvin, ed. and trans. Henry Beveridge (Edinburgh, 1844), vol. 1, xc, xciv. 
Hooker certainly gave an unflattering account of Calvin's institution of presbyterian polity in Geneva; and this account is a part of the polemical aspect of the Lawes, the aspect in which he was encouraged by members of the English court party, through his friends Cranmer and Sandys in particular. It was this critical account that particularly raised objection in A Christian Letter ${ }^{19}$ whose authors worried about the impact of criticizing one of the faith's great heroes, a criticism that would make the Church's enemies rejoice.

\section{Calvin as a Mortal and Fallible Human Being}

Hooker's notes in the margins of $A$ Christian Letter suggest that he was prepared to deal with both Calvin's strengths, and his weaknesses, as a model, and as a mortal. ${ }^{20}$ Hooker noted the comparison of Theodore Beza and Calvin in their manners, and opined that Beza was followed because he was a more attractive person, Calvin because he was more feared. ${ }^{21}$ Calvin was censorious and difficult as a child, as his family noted but, Hooker observes, "this [is] not to be misliked in him". ${ }^{22}$ Yet even his preaching, "the meanest of all other guifts in him" was so admired that it was said that one admirer would prefer to listen to a sermon of Calvin rather than one by St. Paul, if given the choice. ${ }^{23}$ Hooker would let the irony of this anecdote speak for itself, but clearly there was a problem of disproportionate and spiritually dangerous admiration for Calvin, even of his preaching! And Hooker would apparently be prepared to let his readers judge for themselves the significance of Calvin's criticism of the English hero Henry VIII. ${ }^{24}$ In all, Calvin's record would speak for itself.

19 The nineteenth point. FLE 4:55-64.

20 FLE 4:57.30-58.6. Compare the opinion of Archbishop John Whitgift, Hooker's predecessor in engaging Thomas Cartwright the Puritan: "I reverence M. Calvin as a singular man, and worthy instrument in Christ's church; but I am not so wholly addicted to him, that I will contemn other men's judgments that in divers points agree not wholly with his, especially in the interpretation of some places in the scripture, when as, in my opinion, they came nearer to the true meaning and sense of it in those points than he doth". John Whitgift, Works (Parker Society, 1851), 1.436. See Whitgift's claim to have read and valued Calvin before Cartwright even knew his name. Works 2.268; 2.502.

21 FLE 4:55.11-13.

22 FLE 4:58.30-59.2. See Beza, Life of Calvin, xxii: "a strict censor of everything vicious in his companions". As Hooker appears to excuse Calvin's childhood manner, one wonders if Hooker was also a "difficult child".

23 FLE 4:57.7-12.

24 FLE 4:59.7-8. Hooker notes that Beza had condemned such criticisms by others.

PERICHORESIS $10.1(2012)$ 
Hooker has been criticized for one inaccurate tendency, a "pious fraud": that of implying "that Calvin's original reasons for instituting his system of discipline were pragmatic and that he only put forward the claim that it was of divine origin in order to induce the inhabitants of Geneva to accept it the more readily". ${ }^{25}$ Of course, one cannot doubt Calvin's belief that the discipline of Geneva was based on scriptural warrant, and that it was for that reason superior to other forms. And Hooker recognizes that his contemporaries claim divine "right" for the Presbyterian polity. ${ }^{26}$ But Hooker offers no such "pious fraud"; he does not deny the scriptural ground or claim that Calvin's reasons were entirely pragmatic: he denies that "any one sentence of Scripture" decisively proves that the presbyterian system is inevitable $;^{27}$ that is, he notes, entirely accurately, that the Genevan system is based on a large number of texts, that must be read together in a certain way to achieve the conclusion that the presbyterian system has a unique divine authority. Hooker shows that he can read the same texts in another way, to see the offices of pastors, doctors, elders and teachers as functional rather than permanent. ${ }^{28}$ The whole argument of the Lawes is to show that, although the Genevan system may possibly be permissible, it is genuinely defective measured against scriptural and ecclesiastical standards, and is certainly not inevitable, since questions of the Church's life are to be decided by the Church, and not in Scripture alone. ${ }^{29}$

The Lawes, as published, is a work of controversy, and a very clever one at that; the Preface's sneering picture of the use of the crowds and of weak women in Geneva ${ }^{30}$ is a thinly veiled attack on the Puritan approach in England, and is deliberately meant to be; it is slanted history indeed, but not entirely fiction. ${ }^{31}$ It never questions the right of the church in Geneva to

W. J. Cargill Thompson, "The Philosopher of the Politic Society", ed. by W. Speed Hill, Studies in Richard Hooker, $14 \mathrm{f}$.

Preface 2.2; FLE 1:4.27-32; 3.9; FLE 1:16.8-12; 8.5; FLE 1:42.1-6.

Preface 2.7; FLE 1:10.25.

V.78.6-12; FLE 2:443-447.

Article 20 of the Thirty-Nine Articles had followed Lutheran sources in recognizing the church's authority to make decisions relating to ceremonies and to settle disputes on doctrine.

This picture does not derive from Beza's Life of Calvin.

The essays by Porter, Speed Hill and Grislis in W. Speed Hill, Studies in Richard Hooker, 77-206, to some extent temper Cargill Thompson's overstatement of the limited and polemical nature of Hooker's Lawes. Indeed, Cargill Thompson's account of Hooker as opportunistic, eclectic and a hack in the service of the court could not account for the enduring interest in Hooker. Speed Hill's interesting case for the tension between 
settle its own affairs; it complains about the thorough and uncritical exportation of a local solution to the denigration of legitimate existing structures elsewhere. As Hooker's notes to A Christian Letter make clear, however, it must be admitted that the Genevan polity was a novelty, and mostly an invention of Calvin, and not to admit that shows a regrettable bias. ${ }^{32}$

Hooker can characterize one of Calvin's opinions as seeming "crazed". ${ }^{33}$ And Hooker can remind his whole audience that Calvin did not study theology, but learned it by teaching others. ${ }^{34}$

\section{Calvin as a "Grave and Wise Man"}

Yet Calvin remains a "grave and wise man", ${ }^{35}$ though his opinions are not to be accepted uncritically. For

wise men are men, and the truth is truth ${ }^{36}$. That which Calvin did for the establishment of his discipline, seemeth more commendable then that which he taught for the contenancing of it established. ${ }^{37}$

In fact, it appears that Hooker uses the phrase "grave and learned man" or some variant on it, as a code phrase for John Calvin (and those who agreed with him). Calvin's election in Geneva, for instance, is accompanied by the voice of the people, saying "Wee will haue Caluin that good and learned

Hooker and his collaborators deserves attention in coming to a conclusion about Hooker's opportunism and polemic.

32 FLE 4:63.26-64.11.

33 III.1.12; FLE 1:203.20. Farel had asked Calvin about the baptism of children of popish parents. Calvin's judgment was that it is absurd to baptize them that cannot be reckoned members of our body, because the parents were popish. It is probable that Hooker sees Calvin as "crazed" in the sense that his opinion is inconsistent with his own account of baptism, which Hooker clearly adopts and imitates, and by which, baptism is effective, though the "seed" be invisible. Hooker compares Calvin's opinion unfavourably to the judgement of the Ecclesiastical College of Geneva on a related question. FLE 1.203.28-204.30

34 Preface 2.1; FLE 1:3.15-17. See Beza's description of Calvin's doctorate in law. Life of Calvin, xxii-xxiii.

35 Answer 16; FLE 5:246.2, \& fn $g$.

36 This is a nearly direct quotation from Beza's Life of Calvin, where the dictum is used to identify Calvin with those sent by Christ, or those men who speak for Christ, xx: "I will at once admit that men and truth are very different things". Latin: longe aliud esse hominem quam veritatem, Calvini Opera 21.121. There is irony here, for the slogan was often used to limit the authority of Church Fathers, or Ministers in Geneva in Calvin's absence. FLE 6:417. 
man Christs Minister". ${ }^{38}$ And, significantly, Calvin's distinctive view of the internal witness of the Holy Spirit is attributed to "grave and learned men". 39

Hooker carefully exploits Calvin as an authority when Calvin contradicts some part of the Puritans' platform. ${ }^{40}$ In the Answer to the Supplication, Hooker invokes Calvin to answer his Calvinist adversary Travers' charges of substituting "schoolpointes and questions neither of edification nor of truth", for "the expoundinge of the scriptures and [his] ordinary calling"; for Calvin had commended "the distinctions and helpes of schooles". ${ }^{41}$ When Hooker was charged with tolerating "schoolmen, philosophy and poperie", he was preparing to invoke Calvin's favourable judgment of philosophy, as well as Beza's favourable judgement of Aristotle. ${ }^{42}$ Hooker does note, with some delight, that Calvin would have been part of the church consensus against dissenters on the touchy question in the 1590s on God's authorship of $\sin .^{43}$

Preface 2.3; FLE 1:5.23-24. A quotation from a letter of Jacob Bernhard, FLE 6:407-8. III.8.15; FLE 1:232.16-25. See below for a discussion of Hooker's interpretation of the internal witness of the Holy Spirit. See also Answer 16; FLE 5:245.11-246.3 and 246.g, below.

Although Hooker apparently does not exploit the difference between Calvin and Beza on whether discipline is one of the marks of the church, Whitgift had cited Calvin for the view that the two essential marks of the church are "true preaching of God's word and the right administration of the sacraments" that is, that no form of polity is of the essence. Whitgift, Works 1.185. The opinion that there are but these two marks for the church was expressed in the Augsburg Confession and adopted by the English Articles of Religion.

Answer 16; FLE 5:245.11-246.3 and 246.g. Hooker cites Institutes I.16.9. Note that Calvin is cited in the footnote to illustrate the "grave and wise men" of the text. Is this a code name for Calvin? Compare "grave and learned men" in III.8.15; FLE 1:232.1625, where Calvin may be referred to. See below.

FLE 4.65.10-12. The letter referred to, attributed to Calvin, had called philosophy "the noble gift of God", FLE 4.230, note on 65.11-12. Beza admired the philosopher Aristotle and lectured on him (FLE 4.229, note on 65.10-11). He had re-introduced Aristotle into the university in Geneva, overturning Calvin's preference for the simplified version of Peter Ramus. Hooker much preferred the traditional Aristotle to Ramus, who was the fashionable authority on logic and dialectic among certain humanists. See I.6.4; FLE 1:76.9-13 and 6.493-494.

God is not the author of sin, and this should be the consensus of the whole Christian world, considering the church's previous arbitration of error on this score. That is, according to the "voice of the Church", Calvin included, God is not the author of sin (though he providentially permits it, and providentially provides punishments for it). Dublin 29; FLE 4:138.7-32. It is perhaps worth pointing out that Calvin's church is part 
Hooker refers to Archbishop Whitgift's previous use of Calvin as supporting the official view that the church may make additional laws, ${ }^{44}$ and cites Calvin as allowing different churches to have different customs. ${ }^{45}$ Hooker, like many in his church, sometimes appears to prefer the unofficial "Geneva Bible", which version he seems to quote. ${ }^{46}$ Yet he defends the official version, arguing, with respect to a well-known discrepancy ${ }^{47}$, that both that version and the Genevan version are true, but side-steps the question of which is the more accurate translation. Hooker agrees with Puritan sentiment about the Apocrypha, and indicates that personally he would not read from these writings in church. ${ }^{48}$ This use of scripture and of the Genevan version could indicate that Hooker was certainly familiar with the details of Puritan positions and views, and sometimes sympathized with them, but was prepared to adjust his personal views in the light of church authority, which was above the authority of the Reformed Peter Lombard, John Calvin. ${ }^{49}$

As I have argued elsewhere ${ }^{50}$ on the disputed questions of grace, Hooker maintained a view that resembled that of the strong Calvinist party in certain respects, but differed from Calvin in denying unconditional reprobation and from contemporary Calvinists in denying a limited atonement. For Hooker, grace was, in some sense, resistible, although perseverance was "achieved" by the elect, who could thus not finally defect. In contrast to Calvin's former student Peter Baro, Hooker would maintain the later Augustinian version of predestination, as opposed to the early "Arminian" view, which conditioned predestination on the foresight of merit and vice. But Hooker, like Whitgift's advisers on the Lambeth Articles of 1595, rejected Calvin's conclusion about unconditional reprobation, and tempered Au-

of this consensus, and Calvin a hero in developing it. Neelands, "Predestination", in Companion to Richard Hooker, 196.

$44 \quad$ III.11.13; FLE 1:259.2-3. Whitgift, Works 1.243-245.

IV.13.3; FLE 1:329.21-27.

V.18.1; FLE 2:65.19-21; see Keble's note 1, ii.62; 34.3; FLE 2:143.26-27; see Keble's note 2 , ii. 151 .

47

On the reading of Psalm 105.28; V , 19.2,3; FLE 2:68.26-70.20. For that matter, Hooker even defends the admittedly corrupt version of certain liturgical gospels: V.19.4; FLE 2:70.20-71.6

48 V.20.9,10; FLE 2:79.19-80.19.

49 "Of what accoumpt the Maister of sentences was in the church of Rome, the same and more amongest the preachers of reformed Churches Calvin had purchased: so that the perfectest divines were judged they, which were skilfullest in Calvins writinges". Preface 2.8 ; FLE 1:11.5-8. 
gustine's ambiguous authority for this view with the authority of the councils of the church $^{51}$ that followed Augustine and made decisions in the wake of the Pelagian and Semi-Pelagian movements. Most significantly, Hooker had already parted company with Whitaker, with Whitgift and, for that matter, with Perkins and the "experimental predestinarians" on the question of "assurance". For Hooker, there was a paradox on assurance: the best assurance one could have was derived from a recognition of the weakness of one's faith; perfect assurance was a gift of glory; to presume it here turned one into a damnable Pharisee. ${ }^{52}$

\section{The Internal Witness of the Holy Spirit}

On the question of the internal witness of the Holy Spirit, Hooker took a view different from the one often attributed to Calvin by his followers, yet may have claimed Calvin as agreeing with him. Calvin had occasionally referred to this doctrine in relation to the reading of Scripture by believers. ${ }^{53}$ This was not totally different from Luther's view of the "unshakable certainty of Christ, God's Word", with respect to receiving Christ in the Eucharist, though Calvin certainly disagreed with Luther on the manner of Christ's presence. ${ }^{54}$ And a similar idea to Calvin's had been proposed in the English Reformation by Thomas Cranmer, in 1540, in his Prologue to the Great Bible, where Cranmer has quoted extensively from a Homily of John Chrysostom ipated and rejected. Dublin 38; FLE 4:150.30-151.4.

52 See Neelands, "Richard Hooker and the Doctrine of Assurance", Perichoresis 7.1 (2009): 93-111.

53 For a treatment of Calvin's well-known phrase and the consequent theory of the selfauthenticating character of Scripture, see Institutes I.7.4, 5 (i, 78-81); III.1.1 (i, 537-8); III.1.3, 4 (i, 540-542); III.2.15, 33-37 (i, 560-1, 580-4); Comm 2 Timothy 3:16, where Calvin makes a direct link between the inspiration of the authors of scriptural texts and the witness of the same spirit in those who are enlightened: "The same Spirit who made Moses and the prophets so sure of their vocation now also bears witness to our hearts that He has made use of them as ministers by whom to teach us". Calvin's Commentaries. The Second Epistle of Paul the Apostle to the Corinthians and the Epistles to Timothy, Titus and Philemon, trans. T. A. Smail (Grand Rapids: Eerdmans, 1964), 330. See J. K. S. Reid, The Authority of Scripture (London: Methuen, 1957), 45-51.

54 Luther (1522) had already embedded the notion of unshakable certainty in Christ, God's Word: “... but you yourself in your own conscience must feel Christ himself. You must experience unshakably that it is God's Word, even though the whole world should dispute it. As long as you do not have this feeling, just so long you have certainly not tasted of God's Word". Receiving Both Kinds in the Sacrament (1522), Luther's Works 36 (Philadelphia, PA: Fortress, 1959), 248. 
on the incident of Philip and the Ethiopian eunuch from Acts 8.27-40 to argue that God will help those who try to read or listen to Scripture to understand it:

Therefore let no man be negligent about his own health and salvation: though thou have not Philip when thou wouldest, the Holy Ghost, which then moved and stirred up Philip, will be ready and not fail thee if thou do thy diligence accordingly. All these things been written for us for our edification and amendment, which be born towards the latter end of the world.$^{55}$

Incidentally, in the same Prologue, quoting Gregory of Nazianzen, Cranmer also refers to the importance of the human rational capacity along with the Holy Spirit, a man's wits to help avoid precipitous and eccentric readings of scripture:

For he that shall judge and determine such matters and doubts of scriptures, must take his time when he may apply his wits thereunto, that he may thereby the better see and discern what is truth. ${ }^{56}$

Hooker does clearly acknowledge some important role for the Spirit with respect to assuring us of the truths found in Scripture: the truth of the Scriptures is supplied indeed "by the testimony of the spirit, which assureth our harts therin". ${ }^{57}$

But those using Scripture to argue for a reform of the Church's polity in England had been led by self-centred pride to appeal to the "speciall illumination of the holy Ghost". ${ }^{58}$

And reason (informed by the Spirit) is a better general guide for us to know what are the works of the Spirit than the Spirit itself, since reason is public and interpersonal and the (unmediated) operations of the Spirit are private and not always known to those in whom the operations occur: 
The operations of the spirit, especially these ordinary which be common unto all true christian men, are as we know, things secret and undiscernable even to the very soule where they are, because their nature is of another and an higher kind then that they can be by us perceived in this life. Wherefore albeit the spirit lead us into all truth and direct us in all goodnes, yet bicause these workings of the spirit in us are so privy and secret, we therfore stand on a planer ground, when we gather by reason from the qualitie of things beleeved or done, that the spirit of God hath directed us in both; then if we settle our selves to beleeve or to do any certaine particular thing, as being moved thereto by the spirit. ${ }^{59}$

With respect to the appeal to the Holy Spirit to provide the foundation for the general authority of Scripture in the Church, Hooker makes clear that he accepts, as had Luther and Calvin, the dictum of Saint Augustine:

But should you meet with a person not yet believing the gospel, how would you reply to him were he to say, I do not believe? For my part, I should not believe the gospel except as moved by the Catholic church. ${ }^{60}$

Hooker makes his loyalty to this principle very clear and applies it not to the person not yet believing but rather to the person "bred and brought up" in the church:

And by experience we all know, that the first outward motive leading men so to esteeme of the scripture is the authority of Gods Church. For when we know the whole Church of God hath that opinion of the scripture, we judge it even at the first an impudent thinge for any man bredde and brought up in the Church to bee of a contrarye mind without cause. ${ }^{61}$

This in turn leads Hooker to a supposition of what "grave and learned men"-including perhaps Calvin himself, for he is such a "grave and learned" person, perhaps the archetypal one-mean by the phase "internal dictum was shared by Hooker's reforming hero Henry VIII, by Luther, and by Calvin himself. This dictum was quoted by Luther, WA Bd 6, 561; Bd 10.2, 216; by Henry VIII, "the hearts of the faithful more ancient than the books", Assertio, 356; and by Calvin, Institutes I, 7, 3 (i, 76), where Calvin carefully interprets Augustine, along the lines of Luther, so that Augustine's words are made to apply to strangers to the faith, not faithful Christians. In this, Hooker's interpretation clearly departs from Calvin, but remains closer to Augustine as the tradition had interpreted him. 
witness of the Holy Spirit": a concurrence with reason and the voice of the Church that have gone before (not a separate authentication of the authority of Scripture) that leads us to have faith in that authority, in the way that the inducements of understanding (notitia) and assent (assensus) are normally included in trusting faith (fiducia) and hope, which only the Holy Spirit may give. This pattern had been pointed out earlier in the Reformation by Luther and Calvin and in the theological tradition that preceded the Reformation:

Neither can I thinke that when grave and learned men do sometime hold, that of this principle [the authority of Scripture] there is no proofe but by the testimony of the spirit, which assureth our harts therin, it is their meaning to exclude utterly all force which any kind of reason may have in that behalfe; but I rather incline to interpret such their speeches, as if they had more expresly set downe, that other motives or inducements, be they never so strong and consonant unto reason, are notwithstanding uneffectual of them selves to worke faith concerning this principle, if the special grace of the holy ghost concur not to the inlightning of our minds. ${ }^{62}$

Recently, Hooker has been interpreted as following a common Reformation thread on this question, by adopting the later Calvinist interpretation of the self-authenticating authority given to Scripture by the internal witness, "independent of the authority of the church" ${ }^{63}$

III.8.15; FLE 1:232.16-25. It seems clear that Hooker is differentiating his view from another that is commonly held. It is a matter of "concurrence" of grace with natural reason.

63 There thus remain problems in some treatments of Hooker's Calvinism. One recent treatment of Hooker's loyalty to the Reformation is perhaps worthy of extended attention at this point. Nigel Atkinson, Richard Hooker and the Authority of Scripture, Tradition and Reason. Reformed Theologian of the Church of England (Carlisle: Paternoster Press, 1997), argues that "Hooker's celebrated use of reason, tradition and Scripture was not something unique to Hooker in particular or to Anglicanism in general". This, the author believes, may help in a contemporary apprehension of the "Church of England's true theological position", which is apparently a particular Reformed position. (See Atkinson, 132) It is not clear what value there would be in arguing that Hooker's position on these or other matters was unique. Hooker was arguing, in fact, that he spoke for a consensus that had emerged over forty years, although he did not deny that his arguments in defence of that consensus had some novelty. And it is certainly worth pointing out that inherited treatments of Hooker's view of Scripture, reason and tradition are inaccurate. See Neelands, "Hooker on Scripture, Reason and 'Tradition", Arthur Stephen McGrade, Richard Hooker and the Construction of Christian Community (Tempe, AZ: Medieval \& Renaissance Texts and Studies, 1997), 75. Further, Reformers themselves 
But this view of later Calvinists enshrined in the Westminster Confes$\operatorname{sion}^{64}$ was not shared by earlier reformers, and did not appear in the Thirty-

were not uniform in their approaches. In any case, Atkinson's treatment of Hooker's subtle view on the internal witness of the Holy Spirit fails to live up to the intention.

To make Hooker consistent with Atkinson's views of the Reformation and the true current character of the Church of England, Atkinson argues that it would be a mistake to interpret Hooker as "implying that the authority of Scripture is in fact dependent upon the authority of the Church". It is true that, for Hooker, the authority of Scripture is not totally dependent on the authority of the Church. Hooker speaks of the Church providing the "first outward motive" to esteem Scripture: "And by experience ... mind without cause". (III.8.14; FLE 1:231.20-25, cited above) Atkinson goes to some pains to insist that this does not (as indeed it does not) deny that there may be an "inner motive". He comes to write: "To be sure Hooker never uses the term 'inner motive', but to all intents and purposes he is underlining the common Reformation concept of the internal witness of the Holy Spirit when he writes that", and here he quotes the next sentence from Hooker, "Afterwards the more we bestow our [sic] labor in reading or hearing the misteries thereof, the more we find that the thing it selfe doth answer our received opinion concerning it. So that the former inducement prevailing somewhat with us before, doth now much more prevaile, when the very thing hath ministred farther reason". (III.8.14; FLE 1:231.25-30.)

What is apparently at stake here is the later Calvinists' well-known and influential treatment of testimonium Spiritus Sanctus internum, and the consequent theory of the selfauthenticating and infallible character of Scripture and of our apprehension of its authority, a view that has been held from time to time by members of the Church of England, and which came to be enshrined in the Westminster Confession, which itself had brief authority in the Church of England. To see Hooker as here referring to this "the internal witness of the Holy Spirit" in contrast to the authority of the Church, as this author thinks we should to interpret Hooker correctly, stretches the sense of this passage, which would seem to say that it is the "former inducement", that is the opinion of the whole church, which is now stronger in us, through labouring at reading and hearing Scripture. Curiously, the author actually ignores Hooker's reference, within a page of this passage, to the "testimony of the spirit", the very "inner motive' that he believes implied here: "Neither can I thinke ... inlightning of our minds". (III.8.15; FLE 1:232.16-25, cited above). As we have seen, the very secrecy of the operations of the spirit makes this personal and private account unhelpful for teaching and apologetics: "The operations of the spirit... as being moved thereto by the spirit". (III.8.15; FLE 1:232.33-233.9, cited above.) Thus while we must depend on the secret operations of the Spirit for the gift of trusting faith in the authority of Scripture, the public voice of the church and the observable labour of our reason lead to that gift, and are perfected by it not displaced by it, and the gift is trusting faith, not objective certainty. (That Hooker generally found grace to perfect and not destroy nature is argued for in Neelands, "Hooker on Scripture, Reason and 'Tradition"”, 76-82.)

"We may be moved and induced by the testimony of the Church to an high and reverent esteem of the holy Scripture; and the heavenliness of the matter, the efficacy of the doctrine, the majesty of the style, the consent of all the parts, the scope of the whole (which is to give all glory to God), the full discovery it makes of the only way of

PERICHORESIS 10.1 (2012) 
Nine Articles. In 1551, Henry Bullinger the long-lived Zurich reformer, whose views were very influential in the Church of England in the reign of Queen Elizabeth, referenced a less developed account of the internal testimony of the Holy Spirit, precisely to discount "private" interpretation:

... the interpretation of the scriptures is not a liberty to feign what one lust, and to wrest the scriptures which way one wish; but a careful comparison of the scripture, and a special gift of the Holy Ghost; for St Peter saith: "No prophecy in the scripture is of private interpretation". [2 Peter 1:20] Wherefore no man hath power to interpret the scriptures after his own fantasy. ${ }^{65}$

That is, for the careful Bullinger, the "special gift of the Holy Ghost" is not automatic and apparently not self-authenticating, since some will proceed to judge "privately" and incorrectly, as personal interpretation may be at variance with the internal testimony, which is in any case a "special gift", not to mention the importance of reason in a "careful comparison of the scripture".

Hooker, in his turn, knows of the "inner motive" of the "testimony of the spirit" that others have spoken of, but he interprets that in terms of the engracing of the human reason itself, not an interruption of it, which would not actually be all that helpful: the testimony of the holy spirit is in continuity with reason and the voice of the Church, and not an interruption or displacement of either. And this is not incompatible with the view that the authority of Scripture is, in some way, dependent on the Church. In this com-

man's salvation, the many other incomparable excellencies, and the entire perfection thereof, are arguments whereby it doth abundantly evidence itself to be the Word of God; yet, notwithstanding, our full persuasion and assurance of the infallible truth and divine authority thereof, is from the inward work of the Holy Spirit, bearing witness by and with the Word in our hearts". Westminster Confession of Faith (1647), "Chapter I. Of the holy scripture". The phrase "infallible truth" does not represent any element of Hooker's account of the "internal witness of the Holy Spirit: grammatically, the phrase relates to "holy Scripture", but the implication is that it must apply somehow to our "persuasion and assurance", since that it what is at stake in the section. Compare the impatient words of Oliver Cromwell to the General Assembly of the Church of Scotland on the relationship between human inerrancy and the interpretation of Scripture: "I am persuaded that divers of you, who lead the people, have laboured to build yourselves upon the Word of God. Is it therefore infallibly agreeable to the Word of God, all that you say? I beseech you, in the bowels of Christ, think it possible you may be mistaken", ed. by W. C. Abbott, Writings and Speeches of Oliver Cromwell (New York: Russell \& Russell, 1970), 303. 
plex view, it is possible that he enlists Calvin himself, the "grave and learned man". Hooker is not using the (later) discourse of the Westminster Confession, which speaks of "our full persuasion and assurance of the infallible truth and divine authority [of Scripture, deriving] from the inward work of the Holy Spirit”.

Hooker, like many of Reformed persuasion, found that reason and the voice of the Church were sufficient objective grounds for the authority of Scripture, and the claims to "inner motives", though not to be rejected, could be dangerous in the mouths of unreasonable persons. In other words, there were differences of opinion on this within the Reformed household, and Hooker's views were not less Reformed because they were not the Reformed orthodoxy that was to be.

\section{Hooker as a Calvinist}

Hooker was, nevertheless, identifiable as a Calvinistic theologian, although not an unconditional one, and despite these selectively independent positions. As we have noted, on the questions of sanctification ${ }^{66}$ and of the instrumentalist account of Christ's presence in the Eucharist ${ }^{67}$, Hooker and the Church of England largely adopted an account like Bucer's and Calvin's, even though the official Thirty-Nine Articles of Religion were silent on both.

In the next century, Hooker would seem to Henry Hammond as "on the Calvinist side" ${ }^{68} \mathrm{He}$ is thus recognized, despite his differences, with reference to the Calvinist views on predestination and grace, both as an orthodox Calvinist in some ways, especially in comparison with the later English Arminians with whom he also shared some views, and yet as a "bridge figure", pointing ahead as well to the eventual rejection of Calvinism by an increasing majority of English divines after the Synod of Dort. ${ }^{69}$

At least one important divine of the next century, Robert Sanderson, did use Hooker as such a "bridge": he first read Calvin as recommended, later

Neelands, "Justification and Richard Hooker the Pastor", Lutheran and Anglican. Essays in Honour of Egil Grislis (Winnipeg: St. John's College Press, 2009), 171-176.

$67 \quad$ Neelands, "Christology and Sacraments", 382-398.

68 Henry Hammond, Pacifick Discourse, 9-10. The assertion seems to be based on one of Sanderson's letters. Dewey D. Wallace, Jr. Puritans and Predestination. Grace in English Protestant theology, 1525-1695 (Chapel Hill, NC: University of North Carolina Press, 1982), 126, note 78.

69 This is G. P. Fisher's older assessment of the Dublin Fragments. History of Christian Doctrine (Edinburgh: T\&T Clark, 1896), $353 f$. 
read Hooker and, on the topic of election, moved away from the "harshness" of Calvin and Beza, as interpreted in English Calvinism, but without accepting the English Arminian view. ${ }^{70}$

When it comes to matters of predestination and assurance, it would perhaps be preferable to see Hooker as a pre-Dortian English Augustinian, within the general framework of assumptions of English Calvinism, but deviating from his contemporaries in his scholastic conviction that the image of God in the human being was not obliterated by the Fall, and in the clear rejection of "experimental predestination", in favour of a practical and evangelical hopefulness, that preached a trust in God's mercy in Christ and the need for watchfulness and labour, since "there can be no such absolute decree... as on our part includeth no necessity of care and travail".

With respect to the internal witness of the Holy Spirit, Hooker was within the line from Cranmer on, acknowledging the help of the Holy Spirit in interpreting scripture, as part of the authority of the church and of reason, and not in opposition to the authority of the church. Further, he may have claimed that Calvin was in agreement with him.

\section{Bibliography}

Atkinson, Nigel. Richard Hooker and the Authority of Scripture, Tradition and Reason. Reformed Theologian of the Church of England. Carlisle: Paternoster Press, 1997.

Beza, Theodore. Life of John Calvin. Edited and translated by Henry Beveridge. Selected Works of John Calvin. Edinburgh, 1844.

Cragg, Gerald R. From Puritanism to the Age of Reason. A Study of Changes in Religious Thought within the Church of England, 1660 to 1700. Cambridge: Cambridge University Press, 1950.

Bray, Gerald. Documents of the English Reformation. Cambridge: J. Clarke, 1994.

Bullinger, Heinrich. The Decades of Henry Bullinger. Translated by H. I. Edited for the Parker Society by Thomas Harding. Cambridge: Cambridge University Press, 1849-1852. 
Cranmer, Thomas. The Works of Thomas Cranmer, Archbishop of Canterbury, Martyr 1556. Edited for the Parker Society by John Edmund Cox. Cambridge: Cambridge University Press, 1844.

Fisher, George Park. History of Christian Doctrine. Edinburgh: T\&T Clark, 1896.

Hargrave, O. T. The Doctrine of Predestination in the English Reformation. Unpublished PhD thesis. Vanderbilt University, Nashville, Tennessee, 1966.

Hill, W. Speed, ed. Studies in Richard Hooker. Cleveland, OH: Case Western Reserve, 1972.

Hooker, Richard. The Folger Library Edition of the Works of Richard Hooker. General Editor W. Speed Hill. Cambridge, MA: Belknap Press of Harvard University Press, 1977-1998.

McGrath, Alister E. A Life of John Calvin. Oxford: Basil Blackwell, 1990.

Neelands, David. "Christology and the Sacraments", Companion to Richard Hooker. Edited by W. J. Torrance Kirby. Leiden: Brill, 2008, pages 369402.

. "Hooker on Divinization: Our Participation of Christ", From Logos to Christos. Essays in Christology in Honour of Joanne McWilliam. Edited by Ellen M. Leonard and Kate Merriman. Waterloo: Wilfrid Laurier University Press, 2010.

. "Hooker on Scripture, Reason and 'Tradition", Richard Hooker and the Construction of Christian Community. Edited by Arthur Stephen McGrade. Tempe, AZ: Medieval \& Renaissance Texts \& Studies, 1997.

. "Justification and Richard Hooker the Pastor", Lutheran and Anglican. Essays in Honour of Egil Grislis. Winnipeg: St. John's College Press, 2009, 167-182.

. "Peter Martyr Vermigli and the Thirty-Nine Articles of the Church of England", A Companion to Peter Martyr Vermigli. Leiden: Brill, 2009, 355-374.

. "Predestination", A Companion to Richard Hooker. Edited by W. J. Torrance Kirby. Leiden: Brill, 2008, 185-219.

. "Richard Hooker and the Doctrine of Assurance", Perichoresis 7.1 (2009): 93-111.

. The Theology of Grace of Richard Hooker. Unpublished ThD thesis. Trinity College and the University of Toronto, 1988.

Reid, John Kelman Sutherland. The Authority of Scripture. London: Methuen, 1957. 
Sanderson, Robert. Works (Oxford: Oxford University Press, 1854).

Wendel, François. Calvin (London: Collins, 1965).

Whitgift, John. The Works of John Whitgift, D. D. Master of Trinity College. Edited for the Parker Society, by the Rev. John Ayre. Cambridge: Cambridge University Press, 1851-1853.

PERICHORESIS 10.1 (2012) 